\title{
MEIS1, a Promising Candidate Gene, Is Not Associated with the Core Symptoms of Antipsychotic-Induced Restless Legs Syndrome in Korean Schizophrenia Patients
}

\author{
Seung-Gul Kang ${ }^{1}$, Heon-Jeong Lee ${ }^{2 凶}$, Seung-Hwan Lee ${ }^{3}$, and Leen Kim ${ }^{2}$ \\ ${ }^{1}$ Department of Psychiatry, Gil Medical Center, Gachon University School of Medicine, Incheon, Republic of Korea \\ 2Department of Psychiatry, Korea University College of Medicine, Seoul, Republic of Korea \\ ${ }^{3}$ Department of Psychiatry, Inje University College of Medicine, Goyang, Republic of Korea
}

Objective Restless legs syndrome (RLS) is a distressing sleep disorder to which individuals appear to be genetically predisposed. In the present study, we assumed that antipsychotic-induced RLS symptoms were attributable to differences in individual genetic susceptibility, and investigated whether MEIS1, a promising candidate gene, was associated with antipsychotic-induced RLS symptoms in schizophrenia patients.

Methods All subjects were diagnosed with schizophrenia by board-certified psychiatrists using the Korean version of the Structured Clinical Interview for DSM-IV. We assessed antipsychotic-induced RLS symptoms in 190 Korean schizophrenic patients using the diagnostic criteria of the International Restless Legs Syndrome Study Group. Genotyping was performed for the rs 2300478 and $r s 6710341$ polymorphisms of the MEIS1 gene.

Results We divided subjects into RLS symptom ( $\mathrm{n}=96)$ and non-symptom ( $\mathrm{n}=94)$ groups. There was no significant between-group difference in the genotype or allele frequencies of the two polymorphisms investigated, nor in the frequency of the $r s 2300478$ - $r s 6710341$ haplotype.

Conclusion Our data do not suggest that the $r s 2300478$ and $r s 6710341$ polymorphisms of the MEIS1 gene are associated with the core symptoms of antipsychotic-induced RLS in schizophrenia; different genetic mechanisms may underlie antipsychotic-induced vs. primary RLS.

Psychiatry Investig 2015;12(2):263-267

Key Words MEIS1 gene, Polymorphism, Restless legs syndrome, Antipsychotics, Schizophrenia.

\section{INTRODUCTION}

Restless legs syndrome (RLS), a sleep disorder characterized by uncomfortable sensations in, and irresistible urges to move, the legs, affects the quality of sleep and life. RLS is classified into primary and secondary types. Although the pathophysiology of primary RLS is not fully understood, some evidence suggests that it is caused by impaired central dopaminergic transmission and genetic factors. A family history of RLS has been reported in $60 \%$ of idiopathic RLS patients, ${ }^{1-3}$ and

Received: November 6, 2014 Revised: December 10, 2014

Accepted: December 23, 2014 Available online: March 18, 2015

$\bowtie$ Correspondence: Heon-Jeong Lee, MD, PhD

Department of Psychiatry, Anam Hospital, Korea University College of Medicine, 73 Inchon-ro, Seongbuk-gu, Seoul 136-705, Republic of Korea

Tel: +82-2-920-6721, Fax: +82-2-929-7679, E-mail: leehjeong@korea.ac.kr

(c) This is an Open Access article distributed under the terms of the Creative Commons Attribution Non-Commercial License (http://creativecommons.org/licenses/by$\mathrm{nc} / 3.0$ ) which permits unrestricted non-commercial use, distribution, and reproduction in any medium, provided the original work is properly cited. several genetic RLS loci (2q, 9p, 12q, 14q, 16p, 19p, 20p) have been identified using linkage analysis..$^{4-10}$

Secondary RLS is caused by medical conditions including iron deficiency, chronic renal failure, neuropathy, pregnancy, and the use of medications such as antipsychotics and antidepressants. ${ }^{11}$ Several cases of antipsychotic-induced RLS have been reported, ${ }^{12-14}$ and the RLS incidence in schizophrenia patients is two-fold higher than in healthy controls, probably attributable to antipsychotic use. ${ }^{15}$

Although antipsychotics-induced RLS is generally regarded as being caused by dopamine receptor blockade, we suggest that this RLS may in fact be attributable to individual genetic susceptibilities, as is primary RLS. RLS does not occur in all patients using antipsychotics, some of whom show no symptoms at all. Therefore, we hypothesize that antipsychotic-induced RLS may be associated with differences in biological vulnerabilities to RLS, including genetic differences. To explore this hypothesis, we previously investigated associations be- 
tween antipsychotic-induced RLS and several candidate genes [G protein $\beta_{3}$ subunit (GNB3), tyrosine hydroxylase $(T H)$, monoamine oxidase, dopamine receptor, BTB (POZ) domaincontaining 9 (BTBD9) and circadian genes (i.e., the CLOCK and NPAS2 genes) $]^{16-19}$ and demonstrated probable associations between RLS and the BTBD9, CLOCK, NPAS2, GNB3, and $T H$ genes. ${ }^{16,19-21}$

In 2007, two independent genome-wide association studies (GWAS) were published, indicating a significant association between RLS and several genes not previously considered. ${ }^{22,23}$ Intronic variants of the myeloid ectropic viral insertion site 1 (MEIS1) and the homeobox 1 (MEIS1), mitogen-activated protein kinase 5 (MAP2K5), LBXCOR1 glyoxalase I (GLO1), $B T B D 9$, and dynein axonemal heavy chain (DNAH8) gene, were strongly associated with RLS in the discovery phase of two GWAS. ${ }^{22,23}$ In the GWAS of Winkelmann et al., the $r s 2300478$ polymorphism of the MEIS1 gene exhibited the strongest association with RLS (following Bonferroni correction) in a case/ control sample. ${ }^{23}$ The haplotype consisting of $r s 6710341$ allele A and $r s 12469063$ allele G conferred the greatest risk of RLS. ${ }^{23}$ Several related and replication studies followed, investigating the association between the MEIS1 gene and the primary or secondary RLS caused by end-stage renal disease (ESRD). ${ }^{24-26}$ Therefore, the MEIS1 gene, which exhibited a positive association with both GWAS and secondary RLS caused by ESRD, is a good candidate for control of antipsychotics-induced RLS.

MEIS1, identified by Moskow et al., ${ }^{27}$ is 137360 base-pairs in length and consists of 13 exons on chromosome $2 \mathrm{p} 14 .{ }^{28}$ The MEIS1 protein has 390 amino acids and is expressed in murine hematopoietic stem cells, bone marrow, and fetal liver. ${ }^{29}$ Hematopoiesis and hepatic development were blocked in MEIS1-knockout mice. ${ }^{29,30}$ MEIS1 is also essential for limb formation in the mouse and chicken. ${ }^{31}$ The involvement of MEIS1 in limb formation and hematopoiesis may have implications for RLS development.

We investigated whether the MEIS1 gene was associated with the core symptoms of antipsychotic-induced RLS in schizophrenia.

\section{METHODS}

\section{Subjects}

A total of 190 schizophrenic patients were enrolled from Korea University Hospital and three other collaborating hospitals. All subjects were ethnic Koreans taking antipsychotics. They were diagnosed with schizophrenia by board-certified psychiatrists using the Korean version of the Structured Clinical Interview for DSM-IV. ${ }^{32}$ The exclusion criteria were as follows: 1 ) another Axis I diagnosis, a history of alcohol or other substance abuse, mental retardation, or a head injury or neurological dis- order; 2) a serious medical illness or medical condition which could be mistaken for RLS; and 3) extreme psychotic symptoms preventing interview. The study was approved by the Ethics Committee of Korea University Medical Center, and all participants provided written informed consent.

\section{Clinical assessments}

RLS was assessed using the following four diagnostic criteria of the International Restless Legs Syndrome Study Group (IRLSSG): $:^{33} 1$ ) urge to move the legs, 2) unpleasant sensations in the legs, 3) urge to move or unpleasant sensations in the legs worsening during rest and relieved by bodily movements; and 4) urge to move the legs or unpleasant sensations that worsened or occurred only during the evening/nighttime. To obtain an adequate sample size (equalized across groups) for the genetic association study, we divided patients into the following two groups: a) subjects that met either criterion 1) or 2) of the IRLSSG diagnostic criteria (i.e., core symptoms of RLS); and b) subjects without RLS symptoms. RLS severity was determined using the IRLSSG rating scale for RLS. ${ }^{34}$ The Athens Insomnia Scale was used to assess insomnia severity, ${ }^{35}$ and the psychiatric symptoms of patients were evaluated using the Brief Psychiatric Rating Scale. ${ }^{36}$ The clinical characteristics of schizophrenia patients with antipsychotic-induced RLS have been previously described, ${ }^{15}$ and other findings on such subjects have been reported in previous studies. ${ }^{16-21}$

\section{DNA analysis and genotyping}

We selected the rs 2300478 and rs6710341 polymorphisms of the MEIS1 gene for study, based on previous work, and the known minor allele frequencies in the general Korean population. Genomic DNA was extracted from whole blood using standard methods. Genotyping was performed via high-resolution melting (HRM) curve analysis. Polymerase chain reactions (PCRs) were performed, in a volume of $20 \mu \mathrm{L}$ per reaction, in a 96-well Bio-Rad CFX96 Real Time PCR System (BioRad, Hercules, CA, USA). The missing genotype rates for the rs2300478 and rs6710341 polymorphisms were both $0 \%$.

\section{Statistical analysis}

The presence of Hardy-Weinberg equilibrium was assessed using the $\chi^{2}$ goodness-of-fit test. Categorical data were analyzed using the $\chi^{2}$ or Fisher's exact test, and continuous variables were analyzed using Student's t-test or one-way analysis of variance. Haplotype frequencies were estimated using the SNPAlyze software package (ver. 7, DYNACOM, Chiba, Japan) based on use of an expectation-maximization algorithm and the maximumlikelihood approach. All analyses were performed using SPSS for Windows software (SPSS Inc., Chicago, IL, USA) and SNPAlyze. A value of $\mathrm{p}<0.05$ was taken to indicate statistical sig- 
nificance, but after Bonferroni correction, the threshold was set at $\mathrm{p}<0.025$ (Table 1 and 2), because two single-nucleotide polymorphisms were genotyped in the present study.

\section{RESULTS}

Patient mean age was 39.6 \pm 9.2 years (range: $22-66$ years). Of 190 subjects, 84 (44.2\%) were female and 106 (55.8\%) male; $44(23.2 \%)$ subjects met the IRLSSG diagnostic criteria and 96 (50.5\%) had RLS symptoms. We divided subjects into with core RLS symptom ( $\mathrm{n}=96)$ and non-symptom ( $\mathrm{n}=94)$ groups; 52 of the core RLS symptom group did not meet all IRLSSG diagnostic criteria.

Genotype frequencies did not deviate from Hardy-Weinberg equilibrium $\left(r s 2300478 ; \chi^{2}=2.17, \mathrm{p}=0.141 ; r s 6710341 ; \chi^{2}=\right.$ $1.85, \mathrm{p}=0.174)$. There was no significant group difference in genotype ( $r s 2300478 ; \chi^{2}=1.38, \mathrm{p}=0.503 ; r s 6710341 ; \chi^{2}=1.04$, $\mathrm{p}=0.596)$ or allele frequency $\left(r s 2300478 ; \chi^{2}=0.48, \mathrm{p}=0.489\right.$; $\left.r s 6710341 ; \chi^{2}=0.34, \mathrm{p}=0.561\right)$ for either polymorphism investigated (Table 1 and 2).
Two markers $\left(D^{\prime}=0.9746, \mathrm{r}^{2}=0.9266, \mathrm{p}=1.329 \times 10^{-4}\right)$ exhibited significant linkage disequilibrium (LD). There was no between-group difference in the frequency of the rs2300478rs6710341 haplotype (Table 3).

\section{DISCUSSION}

Recently, several authors have reported cases of antipsychotic-induced RLS, a condition attracting increasing clinical attention. Symptoms of antipsychotic-induced RLS are commonly observed in schizophrenic patients taking antipsychotics; it is also notable that such patients exhibit more severe psychiatric symptoms than do those without RLS symptoms. ${ }^{15}$

However, the pathogenesis of antipsychotic-induced RLS remains poorly understood. Therefore, we suggest that genetic research on this topic is of value; idiopathic RLS has been considered to be a genetic disease in the previous GWAS and replication studies. In particular, MEIS1 is a promising candidate gene. Of the three gene regions, the rs 2300478 polymorphism of the MEIS1 gene exhibited the strongest association

Table 1. Genotypic association analysis between RLS symptoms in schizophrenia and two SNPs of MEIS1 gene

\begin{tabular}{|c|c|c|c|c|c|c|c|}
\hline \multirow{2}{*}{ SNP } & \multicolumn{3}{|c|}{ Genotype frequency } & \multicolumn{4}{|c|}{ Genotypic association analysis } \\
\hline & Genotype & RLS symptoms $(\mathrm{N}=96)$ & No RLS symptom $(\mathrm{N}=94)$ & Model & $\chi^{2}$ & $\mathrm{p}$ value & OR $(95 \% \mathrm{CI})$ \\
\hline \multirow[t]{4}{*}{$r s 2300478$} & GG & $12(12.5 \%)$ & $11(11.7 \%)$ & Recessive & 1.04 & 0.309 & $0.74(0.42-1.32)$ \\
\hline & GT & $33(34.4 \%)$ & $40(42.6 \%)$ & Heterozygous & 1.34 & 0.247 & $0.71(0.39-1.27)$ \\
\hline & $\mathrm{TT}$ & $51(53.1 \%)$ & $43(45.7 \%)$ & Dominant & 0.028 & 0.866 & $0.93(0.39-2.22)$ \\
\hline & & & & Additive & 1.38 & 0.503 & \\
\hline \multirow[t]{4}{*}{$r s 6710341$} & AA & $50(52.1 \%)$ & $43(45.7 \%)$ & Dominant & 0.03 & 0.866 & $0.93(0.39-2.22)$ \\
\hline & AG & $34(35.4 \%)$ & $40(42.6 \%)$ & Heterozygous & 1.02 & 0.313 & $0.74(0.41-1.33)$ \\
\hline & GG & $12(12.5 \%)$ & $11(11.7 \%)$ & Recessive & 0.76 & 0.382 & $0.78(0.44-1.37)$ \\
\hline & & & & Additive & 1.04 & 0.596 & \\
\hline
\end{tabular}

RLS: restless legs syndrome, SNP: single nucleotide polymorphism, MEIS1: Meis homobox 1, OR: odd ratio, CI: confidence interval

Table 2. Allelic association analysis between RLS symptoms in schizophrenia and two SNPs of MEIS1

\begin{tabular}{cccccccc}
\hline \multirow{2}{*}{ SNP } & \multirow{2}{*}{ Gene } & \multirow{2}{*}{ MAF(RLS symptoms) } & \multirow{2}{*}{ MAF (No RLS symptom) } & Risk allele & \multicolumn{3}{c}{ Allelic association analysis } \\
\cline { 6 - 10 } & & & & & $\chi^{2}$ & p value & OR (95\% CI) \\
\hline rs2300478 & MEIS1 & 0.297 & 0.330 & N/A & 0.48 & 0.489 & $0.86(0.56-1.32)$ \\
$r$ s6710341 & MEIS1 & 0.302 & 0.330 & N/A & 0.34 & 0.561 & $1.14(0.74-1.75)$ \\
\hline
\end{tabular}

RLS: restless legs syndrome, SNP: single nucleotide polymorphism, MEIS1: Meis homeobox 1 gene, MAF: minor allele frequency, OR: odds ratio, CI: confidence interval, N/A: not applicable

Table 3. Estimated haplotype frequencies of MEIS1 rs6710341-rs2300478 and the association significance

\begin{tabular}{cccccc}
\hline \multirow{2}{*}{$\begin{array}{c}\text { Haplotype } \\
(r s 6710341-r s 2300478)\end{array}$} & $\begin{array}{c}\text { Overall permutation } \\
\text { p value }\end{array}$ & Overall & $\begin{array}{c}\text { Group w/ RLS } \\
\text { symptoms }\end{array}$ & $\begin{array}{c}\text { Group w/o RLS } \\
\text { symptoms }\end{array}$ & $\begin{array}{c}\text { Permutation } \\
\text { p value }\end{array}$ \\
\cline { 3 - 5 } A-T & & 0.6789 & 0.6927 & 0.6649 & 0.572 \\
G-G & 0.847 & 0.3079 & 0.2916 & 0.3244 & 0.477 \\
G-T & & $7.932 \times 10^{-3}$ & 0.0105 & $5.347 \times 10^{-3}$ & 0.74 \\
A-G & & $5.301 \times 10^{-3}$ & $5.254 \times 10^{-3}$ & $5.347 \times 10^{-3}$ & 0.769 \\
\hline
\end{tabular}

MEIS1: Meis homeobox 1, RLS: restless legs syndrome, w/: with, w/o: without 
with RLS during each stage of replication, and the three stages combined, in Winkelmann's GWAS. ${ }^{23}$ In addition, Xiong et al. ${ }^{24}$ demonstrated a significant association between $r s 2300478$ and $r s 12469063$, and RLS, in 28 patients and 140 control subjects, using autopsy brain samples. ${ }^{24}$ In two previous studies, MEIS1 played important roles in the development of proximo-distal limbs in animal studies, ${ }^{31,37}$ which could represent the underlying mechanism of the association between the MEIS1 gene and RLS.

However, in another GWAS study, using an Icelandic sample, there was no significant association between RLS and the MEIS1 gene region. ${ }^{22} \mathrm{~A}$ replication study in a European population investigated RLS loci including MEIS1 gene polymorphisms ( $r s 6710341, r s 12469063, r s 2300478)$; there was no association between the MEIS1 gene and sporadic RLS, although a significant association was evident in a familial RLS case. ${ }^{25}$ In a genetic study of secondary RLS caused by ESRD, there was no significant association between the MEIS1 gene and RLS in the combined analysis, although there was an association in a German sample that was analyzed separately. ${ }^{26} \mathrm{~A}$ Taiwanese study of RLS caused by ESRD demonstrated a negative association with the MEIS1 gene. ${ }^{38}$ Such inconsistent data might be attributable to differences in genotype or allele frequencies among races. In fact, the rs6710341 genotyped in our study showed a minor allele frequency which is somewhat different from that in the past study. ${ }^{25}$ To validate this result, a replication study on the association of the MEIS1 gene with idiopathic RLS in a Korean sample is required. However, one study in which a relationship between MEIS1 variants and iron homeostasis was observed suggested that the pathophysiologies of idiopathic and antipsychotic-induced RLS differed. ${ }^{39}$

Our study had several limitations. First, the sample size may have been insufficiently large for results to be generalized. Second, the types of antipsychotics taken varied. Third, we used the presence or absence of core RLS symptoms to assign participants to groups, rather than the definitive RLS diagnostic criteria. Based on these limitations, the reported lack of association between the MEIS1 gene and RLS requires validation using a larger population, all of whom are taking identical antipsychotics. Future research should also evaluate the association between RLS and other candidate genes (for primary RLS; MAP2K5, LBXCOR1, GLO1, and DNAH8) reported elsewhere. ${ }^{22,23}$ Such studies would contribute considerably to our understanding of the pathogenesis of antipsychotic-induced and idiopathic RLS, and facilitate clinician selection of the safest antipsychotic for each patient.

\section{Acknowledgments}

This work was supported by the Gachon University research fund of 2012 (GCU-2012-M075).

\section{REFERENCES}

1. Montplaisir J, Boucher S, Poirier G, Lavigne G, Lapierre O, Lesperance P. Clinical, polysomnographic, and genetic characteristics of restless legs syndrome: a study of 133 patients diagnosed with new standard criteria. Mov Disord 1997;12:61-65.

2. Ondo W, Jankovic J. Restless legs syndrome: clinicoetiologic correlates. Neurology 1996;47:1435-1441.

3. Walters AS, Hickey K, Maltzman J, Verrico T, Joseph D, Hening W, et al. A questionnaire study of 138 patients with restless legs syndrome: the 'Night-Walkers' survey. Neurology 1996;46:92-95.

4. Pichler I, Marroni F, Volpato CB, Gusella JF, Klein C, Casari G, et al. Linkage analysis identifies a novel locus for restless legs syndrome on chromosome 2q in a South Tyrolean population isolate. Am J Hum Genet 2006; 79:716-723.

5. Chen S, Ondo WG, Rao S, Li L, Chen Q, Wang Q. Genomewide linkage scan identifies a novel susceptibility locus for RLS on chromosome 9p. Am J Hum Genet 2004;74:876-885.

6. Desautels A, Turecki G, Montplaisir J, Xiong L, Walters AS, Ehrenberg $\mathrm{BL}$, et al. Restless legs syndrome: confirmation of linkage to chromosome 12q, genetic heterogeneity, and evidence of complexity. Arch Neurol 2005;62:591-596.

7. Levchenko A, Montplaisir JY, Dube MP, Riviere JB, St-Onge J, Turecki G, et al. The $14 \mathrm{q}$ restless legs syndrome locus in the French Canadian population. Ann Neurol 2004;55:887-891.

8. Kemlink D, Plazzi G, Vetrugno R, Provini F, Polo O, Stiasny-Kolster K, et al. Suggestive evidence for linkage for restless legs syndrome on chromosome 19p13. Neurogenetics 2008;9:75-82.

9. Levchenko A, Provost S, Montplaisir JY, Xiong L, St-Onge J, Thibodeau $\mathrm{P}$, et al. A novel autosomal dominant restless legs syndrome locus maps to chromosome 20p13. Neurology 2006;67:900-901.

10. Levchenko A, Montplaisir JY, Asselin G, Provost S, Girard SL, Xiong L, et al. Autosomal-dominant locus for Restless Legs Syndrome in FrenchCanadians on chromosome 16p12.1. Mov Disord 2009;24:40-50.

11. Oka Y, Ioue Y. Secondary restless legs syndrome. Brain Nerve 2009;61: 539-547.

12. Horiguchi J, Yamashita H, Mizuno S, Kuramoto Y, Kagaya A, Yamawa$\mathrm{ki} \mathrm{S}$, et al. Nocturnal eating/drinking syndrome and neuroleptic-induced restless syndrome. Int Clin Psychopharmacol 1999;14:33-36.

13. Pinninti NR, Mago R, Townsend J, Doghramji K. Periodic restless legs syndrome associated with quetiapine use: a case report. J Clin Psychopharmacol 2005;25:617-618.

14. Wetter TC, Brunner J, Bronisch T. Restless legs syndrome probably induced by risperidone treatment. Pharmacopsychiatry 2002;35:109-111.

15. Kang SG, Lee HJ, Jung SW, Cho SN, Han C, Kim YK, et al. Characteristics and clinical correlates of restless legs syndrome in schizophrenia. Prog Neuropsychopharmacol Biol Psychiatry 2007;31:1078-1083.

16. Kang SG, Lee HJ, Choi JE, Park JH, Lee SS, Han C, et al. Possible association between G-protein $\beta 3$ subunit C825T polymorphism and antipsychotic-induced restless legs syndrome in schizophrenia. Acta Neuropsychiatrica 2007;19:351-356.

17. Kang SG, Lee HJ, Choi JE, Park YM, Park JH, Han C, et al. Association study between antipsychotics- induced restless legs syndrome and polymorphisms of dopamine D1, D2, D3, and D4 receptor genes in schizophrenia. Neuropsychobiology 2008;57:49-54.

18. Kang SG, Park YM, Choi JE, Lim SW, Lee HJ, Lee SH, et al. Association study between antipsychotic-induced restless legs syndrome and polymorphisms of monoamine oxidase genes in schizophrenia. Hum Psychopharmacol 2010;25:397-403.

19. Cho CH, Kang SG, Choi JE, Park YM, Lee HJ, Kim L. Association between antipsychotics-induced restless legs syndrome and tyrosine hydroxylase gene polymorphism. Psychiatry Investig 2009;6:211-215.

20. Kang SG, Lee HJ, Park YM, Yang HJ, Song HM, Lee YJ, et al. The BTBD9 gene may be associated with antipsychotic-induced restless legs syndrome in schizophrenia. Hum Psychopharmacol 2013;28:117-123. 
21. Jung JS, Lee HJ, Cho CH, Kang SG, Yoon HK, Park YM, et al. Association between restless legs syndrome and CLOCK and NPAS2 gene polymorphisms in schizophrenia. Chronobiol Int 2014;31:838-844.

22. Stefansson H, Rye DB, Hicks A, Petursson H, Ingason A, Thorgeirsson TE, et al. A genetic risk factor for periodic limb movements in sleep. $\mathrm{N}$ Engl J Med 2007;357:639-647.

23. Winkelmann J, Schormair B, Lichtner P, Ripke S, Xiong L, Jalilzadeh S, et al. Genome-wide association study of restless legs syndrome identifies common variants in three genomic regions. Nat Genet 2007;39:10001006.

24. Xiong L, Catoire H, Dion P, Gaspar C, Lafreniere RG, Girard SL, et al. MEIS1 intronic risk haplotype associated with restless legs syndrome affects its mRNA and protein expression levels. Hum Mol Genet 2009; 18:1065-1074

25. Kemlink D, Polo O, Frauscher B, Gschliesser V, Hogl B, Poewe W, et al. Replication of restless legs syndrome loci in three European populations. J Med Genet 2009;46:315-318.

26. Schormair B, Plag J, Kaffe M, Gross N, Czamara D, Samtleben W, et al. MEIS1 and BTBD9: genetic association with restless leg syndrome in end stage renal disease. J Med Genet 2011;48:462-466.

27. Moskow JJ, Bullrich F, Huebner K, Daar IO, Buchberg AM. Meis1, a PBX1-related homeobox gene involved in myeloid leukemia in BXH-2 mice. Mol Cell Biol 1995;15:5434-5443.

28. Steelman S, Moskow JJ, Muzynski K, North C, Druck T, Montgomery JC, et al. Identification of a conserved family of Meis1-related homeobox genes. Genome Res 1997;7:142-156.

29. Hisa T, Spence SE, Rachel RA, Fujita M, Nakamura T, Ward JM, et al. Hematopoietic, angiogenic and eye defects in Meis1 mutant animals. EMBO J 2004;23:450-459.
30. Azcoitia V, Aracil M, Martinez-A C, Torres M. The homeodomain protein Meis1 is essential for definitive hematopoiesis and vascular patterning in the mouse embryo. Dev Biol 2005;280:307-320.

31. Mercader N, Leonardo E, Azpiazu N, Serrano A, Morata G, Martinez $\mathrm{C}$, et al. Conserved regulation of proximodistal limb axis development by Meis1/Hth. Nature 1999;402:425-429.

32. Han OS, Hong JP. Structured Clinical Interview for DSM-IV Axis I Disorder-Korean Version. Seoul: Hana Medical Publishing; 2000.

33. Allen RP, Picchietti D, Hening WA, Trenkwalder C, Walters AS, Montplaisi J, et al. Restless legs syndrome: diagnostic criteria, special considerations, and epidemiology. A report from the restless leg syndrome diagnosis and epidemiology workshop at the National Institute of Health. Sleep Med 2003;4:101-119.

34. Walters AS, LeBrocq C, Dhar A, Hening W, Rosen R, Allen RP, et al. Validation of the International Restless Legs Syndrome Study Group rating scale for restless legs syndrome. Sleep Med 2003;4:121-132.

35. Soldatos CR, Dikeos DG, Paparrigopoulos TJ. The diagnostic validity of the Athens Insomnia Scale. J Psychosom Res 2003;55:263-267.

36. Overall JE, Gorham DR. The brief psychiatric rating scale. Psychol Rep 1962;10:799-812.

37. Azpiazu N, Morata G. Distinct functions of homothorax in leg development in Drosophila. Mech Dev 2002;119:55-67.

38. Lin CH, Chen ML, Wu VC, Li WY, Sy HN, Wu SL, et al. Association of candidate genetic variants with restless legs syndrome in end stage renal disease: a multicenter case-control study in Taiwan. Eur J Neurol 2014; 21:492-498.

39. Catoire H, Dion PA, Xiong L, Amari M, Gaudet R, Girard SL, et al. Restless legs syndrome-associated MEIS1 risk variant influences iron homeostasis. Ann Neurol 2011;70:170-175. 